\title{
Social Environment Support in The Realization of Conservation Spirit Of "Arum Luhuring Pawiyatan Ing Astanira" In State University of Semarang
}

\author{
Puji Lestari ${ }^{1}$, Tijan $^{2}$, Arif Purnomo 3 , Bagja Riyanto ${ }^{4}$ \\ \{pujilestarikrisbiyantoro@mail.unnes.ac.id $\left.{ }^{1}\right\}$ \\ Universitas Negeri Semarang, Indonesia ${ }^{1,2,3,4}$
}

\begin{abstract}
The current research aimed to explore the field support in representing arum luhuring pawiyatan ing astanira as the Conservation Spirit, as philosophical basis of attitude the academic community in university life of Universitas Negeri Semarang (UNNES). The investigates the social environment of university in supporting the implementation of conservation spirit in an effort to realize the scientific culture with conservation insight, and the realization of environmental conservation at the UNNES. The social practice theory of Bourdieu became the analysis tool in this qualitative research for analyzing the field realization. Analysis descriptive with academic community of UNNES including the leader, the students, the lecturers, and education staff as the research subject conducted. The present research conducted by in-depth interview, observation, and through the focus group discussion. The research found that; first, the regulation, which govern the implementation of conservation spirit, the policy taken by the university in strategic plan, the development of curriculum conservation based, and the assistance of students affairs became the part of arena of spirit values realization. Second, operational regulation for implementing the spirit has not socialized maximally, thus the spirit was insignificant in Tridharma of college particularly in students life. Third, it required a social, symbolic, and cultural capital in realizing the conservation spirit. The recommendation proposed based on the research result are the necessary of management that more intensive on the arena of spirit realization of arum in all aspects of university life in order to realize the scientific culture with conservation insight in UNNES.
\end{abstract}

Keywords: Arum Luhuring Pawiyatan Ing Astanira, UNNES, Habitus, Social Environment

\section{Introduction}

Universitas Negeri Semarang (UNNES) is one of the universities, which served as the supporter, driver, enabler and trigger of transformation. As the trigger of transformation then university, including UNNES shall move dynamically. What should do is the teaching changed, as well as the research must be developed, not monotonous. That description ever been stated by the Minister of Education and Culture, M. Nuh in 2014 (cheated on http.unnes.ac.id. 2014). It has been five years, but it was still up to date.

University, college or often called by people as campus, not regardless from the duty of organizing and developing education and supported by the effective management. The management at least is useful for managing the university life, which organize the service and administrative function, education, and learning, as well as the dedication for community. Those duties and functions put the hope of that university, as the civilization center of modern people will provide contribution to the community development. To implement those duties and 
functions, university shall improve its positive image, maintain its dignity in order the people trust remains awake as the civilization center with their main purposes.

Maintain the dignity, duties, function in community as described above, and every university including UNNES either require a support from any individual, social environment internally or people outside of the university. Every individual who become the member of university has the same responsibility to keep the good image, build up the dignity of university through the vision and mission, and the goal set. In its management, UNNES as the Conservation University determines that (The Glory and Fragrant of an Institution Depends on the Participants Itself) or known as arum luhuring pawiyatan ing astanira, as the Conservation spirit.

The spirit of arum luhuring pawiyatan ing astanira, become the grip of life for any individual the part of community of UNNES to keep up the good name of pawiyatan (organization) in accordance with its dignity. By UNNES, this spirit is expected can be the strength and energy, and as the awareness of any individual of academic community together as the part of university community. It is required a synergy of each individual (agent) of member of UNNES and a structure that can be of a domain and capital, to realize the realization of this conservation spirit. It refers to the description of Bourdieu about social practice. Domain in the context of this research used to explore the social environment. The social environment, which supports the spirit of arum luhuring pawiyatan ing astanira in the realization of university as the developer of super civilization, is explored using analysis tool of Bourdieu about domain or field. Many researches focus on the support of the social environment, for example by Shaleh (2014) [1] how the social environment influences one's academic performance. Social environment interpreted as the conditions, which affect the individual behavior, which can be all human, or condition. Then Ghimire and Pimbert (2000) [2] also stated the support of the social environment for conservation.

What meant as social environment is not only as a locus or as a place of that college organizes an agenda of tri dharma, but as the part of arena meant by Bourdieu, that will show concretely about structure in the realization of conservation spirit. Bourdieu describes, a social arena is a place of struggle or maneuver for scrambling source or betting from the limited access. In several literatures, Bourdieu see the field or arena in accordance with the definition of battle arena. Arena according to Bourdieu viewed rationally than structurally [3]. Arena is also defined as the bets up for grabs, for instance; the present of cultural things (life style), intellectual advance (education), decent works, settlement, land, authority (politic), social class, prestige or others - and maybe in the different level with the specification and the degree of concreteness. Arena is a system of social position structured - authorized by individual or institution - a core which defines a situation to be followed by them [4]. Arena or field is a relationship network between the objective position (Bourdieu dalam Wirawan [5]), often more interpreted rationally than structurally. Arena is a dynamic concept, where the change of agent's position will inevitably cause the change of arena structure [6].

Based on the explanation above is understood that to trigger a transformation, UNNES as educational organization shall remain keep up the dignity. Support required by all parties, particularly social environment of UNNES community even outside of UNNES. The current research explores the support of social environment, field, which according to the concept of Bourdieu is field, arena or domain as a room as a place of agent/actor to compete each other to obtain material or symbolic power resources toward the realization of conservation spirit "arum luhuring pawiyatan ing astanira" in UNNES. The field related to the agent because the practices or actions of agent are the habit formed by the field [7]. 


\section{Research Method}

This qualitative descriptive research focuses on the support of social environment in realizeng the conservation spirit of "arum luhuring pawiyatan ing astanira" in UNNES. Social environment observed by using the theory of Bourdieu about field or domain. The research data obtained from the research subject consisting of leader of UNNES, lecturers, education staff, and the students through interview and observation. To obtain the validity of data in this research, the writer use triangulation sources.

\section{Result and Discussion}

The research found that social environment supporting the realization of conservation spirit arum luhuring pawiyatan ing astanira, can be seen from; First, the regulation in social environment. UNNES has determined the regulation organizing the management of university including the implementation of conservation spirit. This conservation spirit confirmed based on the Regulation of Rector No. 6 of 2017 [8]. This regulation issued by meant of describing the conservation spirit and the symbol, which has meaning of house of science the developer of super civilization. As the spirit then arum luhuring pawiyatan ing astanira became the soul, the heart, as well as in depth became the self-awareness, breath of life in University.

The support of this regulation also indicated by the policy taken from the strategic plan of University, curriculum development conservation based, as well as the assistance of student's field. The regulation organized the management of university set to achieve the reputation goal of UNNES, as the part of arena of spirit values realization of arum luhuring pawiyatan ing astanira. The regulation determined in this management bind any individual. Every lecturer has responsibility for reputation; the publication expected could improve the image of organization as the civilization developer. The responsibility to contribute subjected to every lecturer with mechanism of performance sharing division from the university, to the level of faculty, and then divided into the major and program of study. The result, according to the research, this step was not significantly effective touch the awareness of each lecturer. Open communication pattern among the parties in management of university was necessary. In it is governance, UNNES has also determined the existence of policies that aim at the main goal as conservation universities, namely to realize a campus atmosphere that supports protection, preservation and utilization of the environment wisely, through sustainable development with environmental insight and full participation from UNNES member. This policy implemented through a program of obligation to plant for new students, a ban on driving in certain areas on campus, restrictions on paper use, integrated waste management, and so on. Conservation carried out, one of which is the availability of water in the UNNES region, which increasingly depleted. One of the important parts is how conservation carried out for the availability of water in the UNNES region, which is depleting.

Second, support of students, mentor, education staff, and people outside of the university still needed to be improved. Operational regulation for implementing the arum luhuring pawiyatan ing astanira has not socialized maximally, thus it was not significant in (Three Basic Rules) known as tridharma of university particularly in students life. In fact, this spirit known by the students but they do not understand the meaning, even ignoring the spirit that drives the sense of belonging by all academic community. Many factors affected the cognitive structure of students of UNNES, which form their characters. However, the curriculum structure in each 
program of study determined in building up the students' social character was limited. Meanwhile, the curriculum containing conservation was more emphasized the physical and environmental conservation. According to the group discussion result with student informant, in depth socialization concerning the importance of conservation spirit for maintaining the good image of institution in the material of new student's acceptance was required. Moreover, firm regulation and containing sanction for students who violates, particularly in the life outside of university was also necessary. The support of people around the university became the main factor. Many houses which the ownership were not the local people, it was affected the domain of students interaction patterns. Sometime, people also not responsive toward the student's socialization because of in social culture, the university did not communicate with the people around the university.

Internally, the contention about the meaning of lecturer's tasks in tri dharma of university with the spirit of arum luhuring pawiyatan ing astanira still occurred. Several issues; keep up the reputation of institution is not only through the scientific publication, the improvement of learning quality in class remain became the interesting issue for luhuring pawiyatan (nobleness of institution) particularly related to the UNNES as one of educational institutions of teacher training staff, and the issue of the importance of exemplary.

Exemplary became the important thing in realizing the conservation spirit. Exemplary in performance, attitude, and behavior were required in the management of university because affected the interaction patterns, such as between the lecturers with students, leader with the staff, etc... The development of social character also became the need for building up the attitude and behavior of care, trust in the academic atmosphere. In institution, for maintaining the reputation of university, the students' satisfaction became the thing cannot ignore.

Third, the necessary of social, symbolic, and cultural capital is in realizing this conservation spirit. Social capital obtained by building up the trust. Buildings up the trust of other parties are such as (people, stakeholder, and user) to the university, the trust among individual of UNNES. This climate was necessary to be built beside to be conducted by decreasing the issues about political practice entering the university. Furthermore, the symbolic capital can be achieved through the achievements of university particularly which useful for community which surely achieved through the reputation that increasing the prestige, through all individual of academic community particularly the students. The last is cultural capital which strengthening the identity of UNNES through the vision and mission, the goals and all programs reflected the brand/image of conservation university. This cultural capital also related to habitus, a habit that UNNES members repeat as conservationists. Each individual is accustomed to taking care of the waste, paperless, not wasteful in using electricity on campus, saving water use, not damaging the environment, and other conservation behaviors.

According to the research result, it understood that the conservation spirit of arum luhuring pawiyatan ing astanira became the responsibility of each individual the member of academic community of UNNES. In its social environment, every individual work, carrying out his or her role. As described by Bourdieu by depicting them as an agent who not act in a vacuum but they are in real social situation managed by a series of objective social relations [9]. In this part clearly can be seen how the social environment, social relations between the lecturers, education staff, and students in academic community built through the social culture, supported this spirit which require exemplary and social character. This classification consists of Economic capital, social capital (various type of valuable relation with other meaning parties), cultural capital (valid knowledge to each other) and symbolic capital (prestige and social image). The point is, the support of social environment in achieving the conservation spirit of arum luhuring pawiyatan ing astanira creates a trust required by the university. It is in accordance with the 
explanation of Bourdieu, that the valid interest in this arena is produced by the same historical process which produce the arena itself [4]. Spirit also needs to support the existence of a sustainable campus development policy. As has been described by Pharamesti [10], that UNNES is a campus that uses the concept of a sustainable approach in its development in the city of Semarang. Thomashow (2009) in Pharamesti explained that a sustainable campus is a campus that implements the vision of its ecological area with technology, character, and programs that create and shape eco-friendly lifestyles for people who are part of the campus. That is, in order to realize the conservation concept in this UNNES campus, the support of every academic community within it must be there. Sustainable at the implementation of campus conservation development, means that UNNES gradually harmonizes all aspects of the environment, social and cultural aspects and its economy in order it becomes a campus that is environmentally friendly, comfortable.

The recommendation based on the research result is the necessary of more intensive management in regulation, management in realizing the spirit of arum luhuring pawiyatan ing astanira in all aspects of life in university in order to realize the scientific culture conservation based in UNNES. Several things shall be considered such as the improvement of student's satisfaction in service.

\section{Conclusion}

The spirit of arum luhuring pawiyatan ing astanira, become the grip of life for any individual the part of community of UNNES to keep up the good name of pawiyatan (organization) in accordance with its dignity. By UNNES, this spirit is expected can be the strength and energy, and as the awareness of any individual of academic community together as the part of university community. It is required a synergy of each individual (agent) of member of UNNES and a structure that can be of a domain and capital, to realize the realization of this conservation spirit. The research found that; first, the regulation, which govern the implementation of conservation spirit, the policy taken by the university in strategic plan, the development of curriculum conservation based, and the assistance of students affairs became the part of arena of spirit values realization. Second, operational regulation for implementing the spirit has not socialized maximally, thus the spirit was insignificant in Tridharma of college particularly in student's life. Third, it required a social, symbolic, and cultural capital in realizing the conservation spirit. The recommendation proposed based on the research result are the necessary of management that more intensive on the arena of spirit realization of arum in all aspects of university life in order to realize the scientific culture with conservation insight in UNNES.

\section{References}

[1] M. Shaleh, "Effect of Motivation, Family Factors, Campus Environment and Active Organization on Academic Achievement," J. Pendidik. MIPA, 2014.

[2] J. Brüggemann, K. B. Ghimire, and M. P. Pimbert, Social change and conservation: Environmental politics and impacts of national parks and protected areas. London: Earthscan, 1997.

[3] G. Ritzer and J. Stepnisky, Modern sociological theory. Sage publications, 2017.

[4] R. Jenkins, Membaca Pikiran Pierre Bourdieu. Bantul: Kreasi Wacana Offset, 2016.

[5] I. Wirawan, Social Theories in Three Paradigms: Social Facts, Social Definitions and Social Behavior. Jakarta: Kencana Prenada Media Group, 2012.

[6] P. Bourdieu, Arena Produksi Kultural Sebuah Kajian Sosiologi Budaya. Bantul: Kreasi Wacana, 2016.

[7] C.-F. Shi, "Mapping out gender power: A Bourdieuian approach," Fem. Media Stud., vol. 1, no. 1 , pp. 55-59, 2001. 
[8] T. Puji Lestari, A. Suhardiyanto, and D. Hermawan, "The Development of 'Arum Luhuring Pawiyatan Ing Astanira' As a Part of Scientific Environment in Conservation Insight at Universitas Negeri Semarang,” KnE Soc. Sci., pp. 525-529, 2019.

[9] P. Bourdieu, "Social space and symbolic power," Sociol. theory, vol. 7, no. 1, pp. 14-25, 1989.

[10] N. Phramesti, Rubby dan Yuliastuti, "UNNES Sustainability Study as a Conservation Campus (Case Study of Sekaran UNNES, Semarang),"J. Tek. Perenc. Wil. Kota, vol. 2, no. 1, 2013. 